УДК 619:616-091:579.882:636

(C) 2016

Колич Н. Б., кандидат ветеринарних наук

Національний університет біоресурсів та природокористування України

\title{
ОСОБЛИВОСТІ ПАТОМОРФОЛОГІЧНИХ ЗМІН ЗА АСОЦІАТИВНОГО ПЕРЕБІГУ МІКОПЛАЗМОЗУ
}

\section{Рецензент - доктор ветеринарних наук М. В. Скрипка}

Мікоплазмозна пневмонія свиней - це хронічна інфекиійна хвороба свиней усіх вікових груп, щзо характеризується ексудативно-проліферативним запаленням легень, непостійною лихоманкою, кашлем $i$ затримкою росту та розвитку поросят, а в разі ускладнень - прогресуючим схудненням. Мікоплазмоз підвищує сприйнятливість свиней до вторинних інфекцій, щзо робить його перебіг більш важким $і$ часто призводить до загибелі тварин. Було проведено комплексне лабораторне дослідження із застосуванням бактеріологічних, серологічних та копрологічних методів досліджень поросят віком 1,5 та 3 місяиі. Дослідження проводились в умовах господарства по вирощуванню та відгодівлі свиней у Полтавській області. Характерним для всіх випадків загибелі тварин було нерівномірне почервоніння та незначне потовщення шкіри в ділянці черева. Відмічали збільшення та нерівномірне забарвлення підщелепових, трахеальних, пахових лімфатичних вузлів. Легені з ознаками катаральної бронхопневмонії з ураженням переважно краніальних часточок. Одні ділянки темно-червоного забарвлення з синюшним відтінком, більш щільної консистениії, западають над загальною поверхнею, в просвіті бронхів - слизова маса. Інша частина органу набуває слабко вираженої горбистості у тварин віком 1,5 місяиі і більш виразної- у тварин віком 3 місяиі. В усіх випадках загибелі поросят - перикард та плевра з крововиливами. Селезінка дифузного темночервоного кольору. Нирки світло-коричневого кольору з ділянками синюшного забарвлення. У тварин віком 1,5 місяиі на слизовій оболонці товстого відділу кишечнику зареєстровано округлі множинні дрібні утворення, які виступають у просвіт кишечнику.

Ключові слова: мікоплазмоз, патоморфологічні зміни, свині, легені.

Постановка проблеми. Для поліпшення забезпечення населення важливим продуктом харчування, яким $\epsilon$ м'ясо, провідна роль належить свинарству - найбільш розвинутій галузі тваринництва, здатній у стислі терміни забезпечити населення продуктами харчування. Вирішення цієї проблеми пов'язано зі стійким благополуччям господарств щодо захворювань незаразної та інфекційної етіології. Розвиток свинарства на промисловій основі загострило в числі багатьох інших проблему збереження репродуктивних здібностей маточного стада. Економічні збитки від мікоплазмозу обумовлені зниженням маси тіла тварин, втратою племінних якостей, уповільненням росту і розвитку, загибеллю поросят i значними витратами на лікування та оздоровчі заходи. Нині широко дискутується питання про першорядну роль мікоплазм у патогенезі захворювань зі змішаною етіологією, їх сукупній дії 3 іншими бактеріями та вірусами. Загальної відповіді бути не може, але мікоплазми, будучи самостійною групою, в співдружності з іншими мікроорганізмами посилюють свою патогенну дію. Особливе значення це явище набуло в останні роки, тому що в умовах господарств, особливо великих, все частіше одночасно виявляються декілька інфекцій. Мікоплазмоз підвищує сприйнятливість свиней до вторинних інфекцій, що робить його перебіг більш важким, часто приводячи до загибелі тварин.

Аналіз останніх досліджень і публікацій, у яких започатковано розв'язання проблеми. Мікоплазмозна пневмонія свиней - це хронічна інфекційна хвороба, що характеризується ексудативно-проліферативним запаленням легень, непостійною лихоманкою, кашлем і затримкою росту поросят $[2,6] .3$ огляду на високу захворюваність свиней і хронічний перебіг мікоплазмозна пневмонія свиней завдає великих економічних збитків, які складаються із загибелі i вибракування тварин, а також із витрат на лікування та оздоровчі заходи [1]. Лабораторна діагностика мікоплазмозів потребує вдосконалення, так як під час виділення збудників цих хвороб використовують складні мікробіологічні і культуральні методи, поки ще недоступні для більшості лабораторій [4, 7].

У зв'язку з цим досить актуальним $\epsilon$ проведення своєчасної діагностики мікоплазмозу в асоціації 3 супутніми мікроорганізмами, що дасть змогу виявляти хворих тварин, носіїв i розробляти заходи боротьби з цим захворюванням. Усе це послужило підставою для проведення даних досліджень.

Мета досліджень. Беручи до уваги актуальність проблеми, метою наших досліджень було 


\section{ВЕТЕРИНАРНА МЕДИЦИНА}

вивчення патологоанатомічних змін в організмі поросят 1,5 та 3-місячного віку, що загинули від мікоплазмозу.

Матеріали і методи досліджень. Дослідження проводились в умовах господарства по вирощуванню та відгодівлі свиней Полтавської області. 3 метою відгодівлі в господарстві по розведенню свиней з інтервалом у 2 місяці було придбано поросят віком 1,5 місяці (всього 30 голів). До 3-місячного віку загинуло 50 \% тварин. Було проведено комплексне лабораторне дослідження із застосуванням бактеріологічних, серологічних та копрологічних методів досліджень поросят віком 1,5 та 3 місяці. Було виділено Micoplasma hyopneumoniae та гельмінти нематод Ascaris suum, Trichuris suis та Oesophagostomum dentatum. Патологоанатомічний розтин тварин проводили методом повної евісцерації $[3,5]$.

Результати досліджень. Під час патологоанатомічного дослідження встановлено середню та нижче середньої вгодованості тварин. У тварин, що за життя мали виразні ознаки діареї, встановлено дегідратацію організму, задні кінцівки забруднені напіврідкими фекаліями. Характерним для всіх випадків загибелі тварин було нерівномірне почервоніння та незначне потовщення шкіри в ділянці черева.

Відмічали збільшення та нерівномірне забарвлення підщелепових, трахеальних, пахових, брижових лімфатичних вузлів. Судини кровонаповнені, паренхіма підвищено зволожена, містить крововиливи. Тимус темно-червоного кольору, часточковість органу слабко виражена.

Легені з ознаками катаральної бронхопневмонії 3 ураженням переважно краніальних часточок: осередки темно-червоного 3 синюшним відтінком забарвлення, більш щільної консистенції, западають над загальною поверхнею, в просвіті бронхів - слизова маса. Інша частина органу набуває слабко вираженої горбистості у тварин віком 1,5 місяці і більш виразної - у тварин віком 3 місяці.

Вищезазначені ділянки сірого кольору містять поодинокі крововиливи. Зміни в легенях поросят віком 3 місяці більше виражені. У випадках гострої серцевої недостатності легені набували темно-червоного забарвлення, а на їх поверхні чітко простежувались ділянки ураження. На розрізі тканина ділянок сіро-білого кольору помірно зволожена, просвіти альвеол ділянок ураження не простежуються.

В усіх випадках загибелі поросят - перикард та плевра 3 крововиливами. Епікард нерівномірного забарвлення, на загальному рожевочервоному фоні великі нечітко окреслені ділянки сіро-рожевого забарвлення (більш виражене і в більшій кількості у поросят віком 1,5 місяці) ймовірно ділянки анемії (походження цих утворень на даний час досліджується гістологічним методом).

Епікард передсердь темно-червоного забарвлення $з$ виразними дрібними сіро-білими плямистими осередками, що виступають над загальною поверхнею. У поросят вікової групи 3 місяці поза тим зареєстровано ознаки проліферативного плевриту та перикардиту (перикард та плевра не прозорі, нерівномірно потовщені). Міокард плямистого глинисто-червоного кольору, дряблої консистенції.

Селезінка в одних випадках набувала дифузного темно-червоного кольору, паренхіма підвищено зволожена, орган дряблої консистенції, судини вище середнього кровонаповнення. В інших випадках селезінка мала рожево-сіре забарвлення, краї органу червоно-синюшного кольору, кровонаповнення судин помірне.

Нирки 3 боку капсули плямистого світлокоричневого 3 ділянками синюшного забарвлення. Сечовий міхур середнього наповнення, слизова оболонка від дифузного темно-рожевого до нерівномірного червоно-рожевого кольору, містить дрібні крововиливи.

Спостерігався вогнищевий метеоризм кишечнику. Стінка кишечнику з боку серозної оболонки в усіх тварин мала нерівномірне рожевочервоне забарвлення та кровонаповнення судин $\mathrm{i}$ дещо відрізнялась ступенем патологічних змін у залежності від відділу кишечнику та віку тварин.

Так, у тварин віком 1,5 місяці зареєстровано катаральний ентероколіт. У поросят віком 3 місяці процес набуває більш важкого перебігу - в $50 \%$ це був катаральний ентерит, а в 50 \% - катаральний ентерит, фібринозно-некротичний коліт.

Слід звернути увагу на той факт, що у тварин віком 1,5 місяці на слизовій оболонці товстого відділу кишечнику зареєстровано округлі множинні дрібні утворення, які виступають у просвіт кишечнику і простежуються з боку серозної оболонки (див. рис.).

Не виключено той факт, що на місці таких утворень у тварин надалі розвиваються фібринозно-некротичні процеси. У 100 \% випадків брижа між петлями кишечнику непрозора, потовщена, судини виразного кровонаповнення, у окремих тварин набуває дифузного червоного забарвлення. 


\section{ВЕТЕРИНАРНА МЕДИЦИНА}

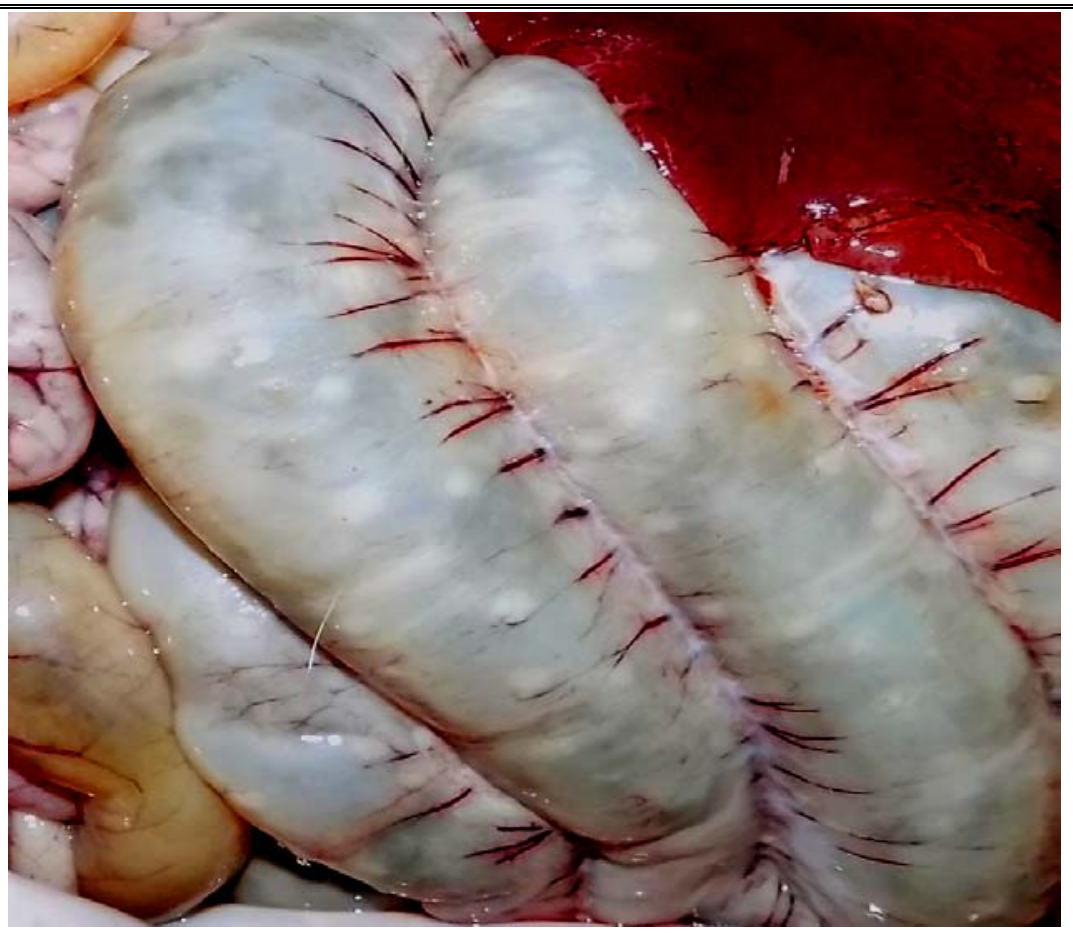

Рис. Кищечник з боку серозної оболонки поросяти віком 1,5 місяці

\section{Висновки:}

1. За асоціативного перебігу мікоплазмозу та нематодозів в органах та тканинах поросят віком 1,5 та 3 місяці патологоанатомічні зміни були схожими, але мали деякі відмінності за ступенем прояву, що в першу чергу пов'язано з віком тварин та ступенем інвазії організму.

2. Характерними були катаральний бронхіт та продуктивна пневмонія, білковий міокардоз, гепатоз та нефроз, серозний лімфаденіт.

3. У тварин віком 1,5 місяці - катаральний ен-

\section{БІБЛІОГРАФІЯ}

1. Андросик Н. Н. Иммуноморфогенез микоплазменной пневмонии свиней / Н. Н. Андросик, А. П. Вель // Актуальные вопросы патологоанатомической диагностики болезней животных. Л., 1982. - С. 244-246.

2. Бердник В. П. Микоплазмоз свиней : автореф. дисс. на соиск. уч. степени д.в.н. - М. : Всесоюзный государственный научно-контрольный институт ветеринарных препаратов, 1991. - 53 с.

3. Горальський Л. П. Основи гістологічної техніки і морфофункціональні методи дослідження у нормі і при патології / Л. П. Горальський, В. Т. Хомич, О. I. Кононський. - Житомир : видво Житомирського ДАЕУ, 2005. - 284 с.

4. Гречухин А. Н. Эффективные средства лечения и профилактики при респираторном симп- тероколіт; у поросят віком 3 місяці до 50 \% випадків захворювання - катаральний ентерит, а в інших - катаральний ентерит та фібринознонекротичний коліт.

Перспективи подальших досліджень: плануються гістологічні і гістохімічні дослідження органів та тканин трупів свиней за асоціативного мікоплазмозу та нематодозів для більш детального вивчення особливостей прояву захворювання на мікроструктурному рівні та аналізу патогенезу захворювання.

томокомплексе свиней / А. Н. Гречухин // Ветеринария. - №8. - 2006. - С. 13-15.

5. Зон Г. А. Патологоанатомічний розтин тварин : навч. посібник / Г. А. Зон, М. В. Скрипка, Л. Б. Іванівська. - Донецьк, 2009. - 190 с.

6. Пустовар А. Я. Иммунологическое обоснование диагностики и профилактики энзоотической пневмонии, сальмонеллеза и некоторых смешанных инфекций свиней : дисс. ... д.в.н. в форме научного доклада / А. Я. Пустовар. - М., 1991. $-49 \mathrm{c}$.

7. Фукс П. П. К вопросу о лабораторной диагностике микоплазмоза / П. П. Фукс, Н. В. Калашник, Г. Б. Геру // Информационный бюллетень ИЭКВМ. - Харьков, 1995. - С. 253-255. 